\title{
In vitro expression of long and short ovine prolactin receptors: activation of Jak2/STAT5 pathway is not sufficient to account for prolactin signal transduction to the ovine $\beta$-lactoglobulin gene promoter
}

\section{Bignon, N Daniel, L Belair and J Djiane}

Unité d'Endocrinologie Moléculaire, Bâtiment des Biotechnologies, Institut National de la Recherche Agronomique, 78352, Jouy-en-Josas, France

(Requests for offprints should be addressed to C Bignon who is now at AFMB-CNRS,

31 Chemin J. Aiguier, 13402 Marseille Cedex 20, France)

\begin{abstract}
The recent finding that sheep had long (1-oPRLR) and short (s-oPRLR) prolactin receptors provided new tools to further explore prolactin signaling to target genes. Here we used CHO cells transfected with 1-oPRLR or s-oPRLR cDNAs to compare the activation of known key steps of prolactin signaling by the two receptors. We found that prolactin stimulated 1-oPRLR tyrosine phosphorylation, although it lacked the last tyrosine residue found in other long prolactin receptors. In addition, 1-oPRLR and s-oPRLR both responded to prolactin stimulation by (1) Janus kinase 2 (Jak2) tyrosine phosphorylation, (2) DNA-binding activation of signal transducer and activator of transcription 5
\end{abstract}

(STAT5), (3) stimulation of transcription from a promoter made of six repeats of STAT5-responsive sequence. However, although it contains STAT5binding consensus sequences, the ovine $\beta$-lactoglobulin promoter $(-4000$ to +40$)$ was transactivated by 1-oPRLR, but not by s-oPRLR. Taken together, our results indicate that activation of Jak2/STAT5 pathway alone is not sufficient to account for prolactin-induced transcription of this milk protein gene, and that sequences of its promoter, other than STAT5-specific sequences, account for the opposite transcriptional activation capabilities of 1-oPRLR and s-oPRLR.

Fournal of Molecular Endocrinology (1999) 23, 125-136

\section{INTRODUCTION}

The prolactin receptor (PRLR) belongs to the superfamily of cytokine receptors. In mammals, cDNA cloning provided evidence that there were three kinds of PRLR. Long forms of PRLR have been described in the rat (Shirota et al. 1990), mouse (Moore \& Oka 1993), human (Boutin et al. 1989), rabbit (Edery et al. 1989), and ruminant species: bovine (Scott et al. 1992), red deer (Jabbour et al. 1996) and ovine (Bignon et al. 1997). A particular feature of the cytoplasmic domain of ruminant long (1)-PRLR is that it terminates about 40 amino acids before that of the other species. The cDNA for a mutant form with an intermediate size was cloned from rat NB2 cells (Ali et al. 1991). Finally, short forms have been described originally in rodents (Boutin et al. 1988, Davis \& Linzer 1989) and, more recently, in ruminants (Bignon et al. 1997, Schuler et al. 1997). Comparative genomic analysis demonstrated that rodents and ruminants used different alternative splicing mechanisms to produce short forms of prolactin receptor (Bignon et al. 1997).

In vitro expression of rodent cDNA coding sequences revealed that long and intermediate, but not short forms, had the capacity to transduce the prolactin signal to a milk protein gene promoter (Ali et al. 1992, O’Neal \& Yu-Lee 1994). During the past few years, key steps of prolactin signaling to target genes have been uncovered. These involve mainly Janus kinase 2 (Jak2) and signal transducer and activator of transcription 5 (STAT5). Jak2 is a quiescent cytoplasmic tyrosine kinase, constitutively associated with long (Dusanter-Fourt et al. 1994), intermediate (Campbell et al. 1994), and short (Lebrun et al. 1995a) prolactin receptors, which becomes transiently tyrosine phosphorylated upon ligand binding. STAT5 is assumed to be the specific substrate of activated Jak2, at least in vitro 
(Gouilleux et al. 1994). By homology with other STATs, the N-terminal half of the molecule is considered as the DNA-binding domain, followed by $\mathrm{SH} 3-$ like, $\mathrm{SH} 2$ and activation domains (Ihle 1996, Moriggl et al. 1996, Stoecklin et al. 1997). Y694, which is located between $\mathrm{SH} 2$ and activation domains of STAT5, has been shown to be the target of Jak2 tyrosine kinase activity (Gouilleux et al. 1994). Once Y694 is phosphorylated, STAT5 dimerizes owing to intermolecular pY694/SH2 interactions and translocates into the nucleus where it promotes transcription of target genes. Two STAT5 ( $a$ and b) have been cloned which are encoded by separate genes (Liu et al. 1995, 1996). Thus, homodimers $(\mathrm{a} / \mathrm{a}$ or $\mathrm{b} / \mathrm{b})$ and heterodimers (a/b) potentially form following prolactin stimulation. Prolactin-induced STAT5a/b heterodimers have been described in NB2 cells (Kirken et al. 1997) and in mouse mammary gland (Liu et al. 1996) by Western blotting. On the other hand, the facts that COS-7 cells transfected with STAT5a transactivate a $\beta$-casein promoter-reporter construct to the same extent as do COS-7 cells transfected with STAT5b (Liu et al. 1995, Stoecklin et al. 1997), and that $\beta$-casein mRNA levels produced by homozygous STAT5a-deficient mice are almost identical to those produced by wild-type mice (Liu et al. 1997), indirectly suggest that functional homodimers also form upon prolactin stimulation. STAT5 binding consensus sequence (TTCNNNGAA) has been found in the promoter of most milk protein genes (reviewed in Vilotte \& Soulier 1992). Evidence for a critical role of this sequence for target gene responsiveness to prolactin has come from deletion experiments (Schmitt-Ney et al. 1992, Demmer et al. 1995).

Until recently, short forms of prolactin receptors seemed to be restricted to rodents, and, consequently, in vitro functional comparative analyses were performed with rodent prolactin receptors only. The recent finding that ruminants also expressed short forms of prolactin receptor has provided new tools to further our understanding of prolactin signal transduction to milk protein genes.

In the present study, we have taken advantage of particular features of the ovine prolactin receptors. The cytoplasmic domain of the long form of the ovine prolactin receptor (1-oPRLR) is shorter than that of the rat (1-rPRLR) and of the rabbit (rbPRLR) by 38 amino acids, which removes the last tyrosine residue present in 1-rPRLR (Y580) and rbPRLR (Y581). The cytoplasmic domain of the short form of the ovine prolactin receptor (s-oPRLR) is also shorter than that of the short form of the rat prolactin receptor (s-rPRLR), and its $\mathrm{C}$-terminal end shares only little homology with the rat sequence. The effects of these differences on the key steps of prolactin signal transduction described above were investigated in $\mathrm{CHO}$ cells transfected with 1-oPRLR and s-oPRLR cDNAs. We suggest that our data provide evidence that, in addition to STAT5-binding sequences, other regions of target gene promoters are required for efficient prolactin signaling.

\section{MATERIALS AND METHODS}

\section{Ovine prolactin}

NIDKK AFP-8277E was provided by the National Hormone and Pituitary Program (Bethesda, MD, USA).

\section{Plasmid constructs}

For eukaryotic expression, the full-length coding sequences of long $(1.75 \mathrm{~kb})$ and short $(0.9 \mathrm{~kb})$ ovine prolactin receptor cDNAs (Bignon et al. 1997) were sub-cloned downstream of a glucocorticoiddependent promoter in pLKneo, an eukaryotic expression vector bearing a resistance gene to G418 (geneticin, Gibco) (Hirt et al. 1992). The two constructs were called 1-oPRLR-pLKneo and s-oPRLR-pLKneo respectively. To assess their functionality prior to selection of stable $\mathrm{CHO}$ cell transfectants, both constructs were checked by CAT assay in transiently transfected $\mathrm{CHO}$ cells, as described below. The rbPRLR-pLKneo construct has been described previously (Goupille et al. 1997).

\section{Stable CHO cell transfectants}

$\mathrm{CHO}$ cells were transfected with $10 \mu \mathrm{g}$ of either 1-oPRLR-pLKneo or s-oPRLR-pLKneo with the calcium phosphate protocol, and transfectants were selected in the presence of $500 \mu \mathrm{g} / \mathrm{ml} \mathrm{G} 418$. Resistant clones were harvested and their capacity to bind ovine prolactin (oPRL) assessed as described below.

\section{${ }^{125}$ I labeling of oPRL}

Ten micrograms of oPRL were incubated with $500 \mu \mathrm{Ci}^{125} \mathrm{I}-\mathrm{Na}$ and $3 \cdot 2 \mu \mathrm{g}$ chloramine- $\mathrm{T}$ for $1 \mathrm{~min}$ at room temperature with gentle shaking. Sodium metabisulfite $(3 \cdot 2 \mu \mathrm{g})$ was then added to stop the reaction, and the iodinated hormone was separated from free iodine by gel filtration on a Sephadex G-25 column (PD10; Pharmacia Biotec, Orsay, 
France), equilibrated (and eluted) with $25 \mathrm{mM}$ Tris (pH 7.5), $10 \mathrm{mM} \mathrm{MgCl}_{2}$ and $0 \cdot 1 \%$ bovine serum albumin (BSA).

\section{Binding experiments}

Each stable CHO clone was grown to confluence in three $35 \mathrm{~mm}$ diameter plates. Sixteen to twentyfour hours before binding, rich medium (HamF12 supplemented with $10 \%$ fetal calf serum) was replaced by GC3 medium (Dulbecco's modified essential medium/HamF12: 50/50, v/v) containing $10^{-6} \mathrm{M}$ dexamethasone to induce expression of the receptor from the glucocorticoid-dependent promoter of pLKneo (Hirt et al. 1992). The cells were then rinsed twice with phosphate-buffered saline (PBS) and incubated at room temperature in $1 \mathrm{ml}$ PBS containing $0 \cdot 1 \%$ BSA and $5 \times 10^{5} \quad$ c.p.m. ${ }^{125} \mathrm{I}$-oPRL (three plates). Non-specific binding was assessed by saturating all prolactin-binding sites; this was achieved by co-incubating the labeling mixture with $1 \mu \mathrm{g}$ unlabeled oPRL (one plate). After 4-h incubation, the cells were rinsed twice with $1 \mathrm{ml}$ PBS containing $0 \cdot 1 \% \mathrm{BSA}$, and lysed with $1 \mathrm{ml} \mathrm{3 \%}$ SDS. The plates were rinsed twice with $0.5 \mathrm{ml}$ water, which was pooled with the lysate. The radioactivity contained in the final $2 \mathrm{ml}$ pool was counted, and the result for each clone was expressed as 'specific binding' for each clone. The specific binding (in c.p.m.) is defined as the mean value of radioactivity recovered from the duplicate plate incubated in the absence of unlabeled oPRL (whole binding) minus the radioactivity recovered from the plate incubated in the presence of unlabeled oPRL (non-specific binding).

\section{Chloramphenicol acetyl transferase (CAT)}

$\beta$-Galactosidase ( $\beta$-gal) (Bignon et al. 1993, 1995) and luciferase (Sotiropoulos et al. 1996) assays have been described already. In brief, $\mathrm{CHO}$ cells or clones were seeded in four $60 \mathrm{~mm}$ diameter dishes in rich medium. The next day, the cells were starved for $16 \mathrm{~h}$ by incubation in GC3 medium. On the third day, the cells were transfected with lipofectamine (Gibco, France), following the manufacturer's instructions, by PCH110, a plasmid encoding the $\beta$-gal activity (Pharmacia), and either by $\mathrm{pBJ} 23$, a plasmid bearing the $(-4000$ to +40$)$ ovine $\beta$-lactoglobulin promoter-CAT reporter (for CAT assay) (Lesueur et al. 1990), or by LHRE-tkluc, a luciferase reporter plasmid made of six repeats of rat $\beta$-casein STAT5-responsive sequence, upstream of a thymidine kinase minimal promoter linked to a luciferase reporter gene (Sotiropoulos et al. 1996) and, when indicated, by 1-oPRLR-
pLKneo, s-oPRLR-pLKneo or rbPRLR-pLKneo. Transfected cells were then incubated for 24 (luciferase assay) or 72 (CAT assay) $\mathrm{h}$ in the presence (two plates) or absence (two plates) of $400 \mathrm{ng} / \mathrm{ml}$ oPRL in GC3 medium containing $10^{-6} \mathrm{M}$ dexamethasone. The plates were washed with PBS, and the enzymatic activities measured as described (Bignon et al. 1993, Sotiropoulos et al. 1996). The results are expressed in fold induction, which is the CAT (or luciferase) activity (divided by the $\beta$-gal activity to take into account the transfection efficiency) ratio of stimulated to unstimulated cells.

\section{Northern blotting}

Northern blotting was essentially as described (Sambrook et al. 1989) and ${ }^{32}$ P-labeled 1-oPRLR cDNA was used as probe.

\section{Western blotting}

Cells were grown and starved as for binding experiments, except that five $100 \mathrm{~mm}$ diameter dishes were used per experimental point. The cells were incubated in the presence or absence of $500 \mathrm{ng} / \mathrm{ml}$ oPRL for $5 \mathrm{~min}$, and then processed as described previously (Daniel et al. 1996). Goat anti-rbPRLR antibody 46 (Dusanter-Fourt et al. 1984) was used for immunoprecipitation. Anti-Jak2 (UBI) antibody was used for immunoprecipitation and blotting. Anti-phosphotyrosine antibody (UBI) was used for blotting only.

\section{Electromobility shift assay (EMSA)}

Electromobility shift assay (EMSA) was performed as described (Pierre et al. 1994, Goupille et al. 1997). In brief, $3 \mu \mathrm{g}$ of nuclear extracts of cells that had been stimulated or not by prolactin for $15 \mathrm{~min}$ were incubated for $25 \mathrm{~min}$ at room temperature with ${ }^{32} \mathrm{P}$-labeled double-stranded oligonucleotide GAGAATTCTTAGAATTTAAA. This sequence spans the region -104 to -85 of the rabbit $\alpha-\mathrm{S} 1$ casein gene promoter and encompasses STAT5-binding site (in bold). The protein/DNA complex formed was separated from the free probe by electrophoresis in non-denaturing polyacrylamide gel. The result was evaluated by autoradiography of the dried gel after transfer onto DE81 paper. When indicated, a 50-fold excess of unlabeled probe, or $1 \mu \mathrm{g}$ anti-STAT5a or b (UBI) or $1 \mu \mathrm{l}$ anti-mammary gland factor (MGF) (Tourkine et al. 1995) antibody were incubated with the nuclear extracts for 15 min at room temperature, prior to addition of the labeled probe. 


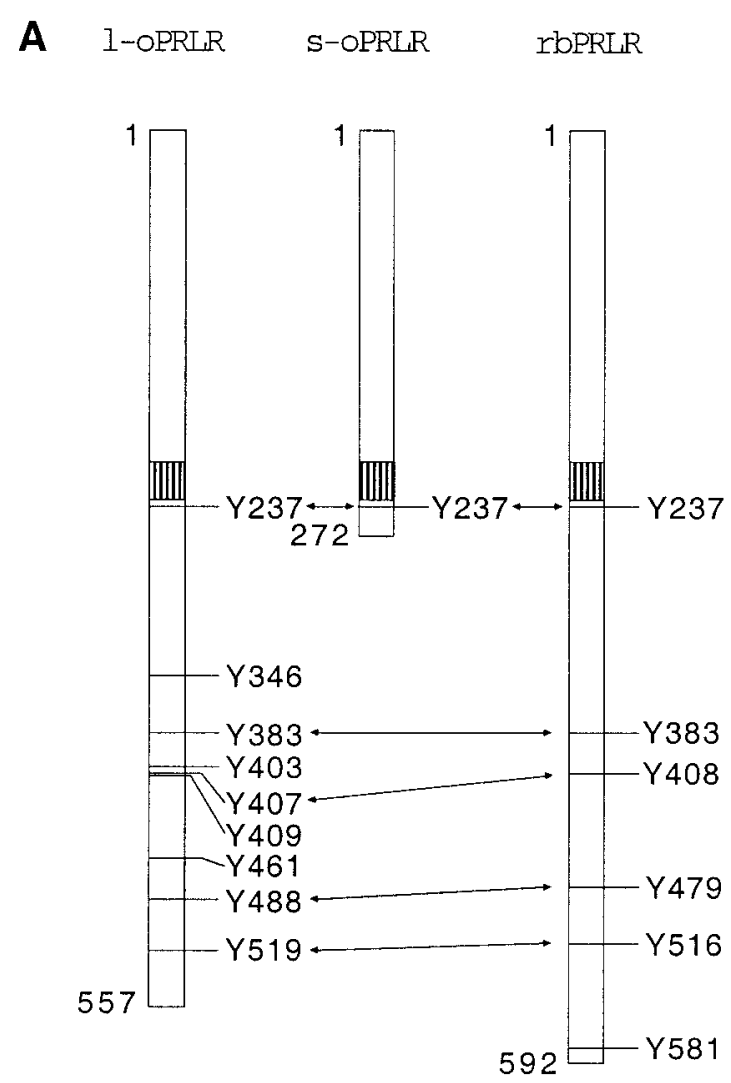

B

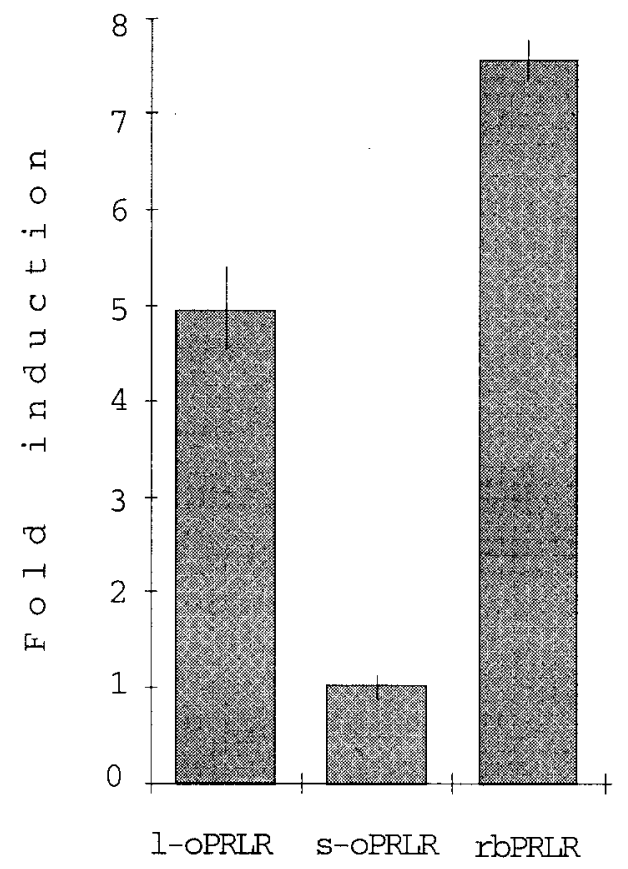

\section{Statistics}

Single pairwise comparisons were carried out by Mann-Whitney test.

\section{RESULTS}

\section{Prolactin-dependent activation of the ovine $\beta$-lactoglobulin promoter transcription by the 1-PRLR but not by the s-PRLR}

In a first trial, transient transfection was used to assess the functionality of the constructs encoding the receptors. To that end, $\mathrm{CHO}$ cells were transiently co-transfected with PCH110 (encoding the $\beta$-galactosidase), $\mathrm{pBJ} 23$ (the $\beta$-lactoglobulin promoter-CAT reporter construct) and plasmids coding for the 1-oPRLR, or the s-oPRLR, or the rbPRLR (Lesueur et al. 1991). The latter was used as a positive control. The three receptors are featured in Fig. 1A. Activation of the target $\beta$-lactoglobulin promoter by prolactin was measured in those cells. As expected, prolactin stimulated transcription of the $\beta$-lactoglobulinCAT construct through the two long receptors (rbPRLR: $7 \cdot 5$ times and 1-oPRLR: 5 times), but not through the short receptor (s-oPRLR) (Fig. 1B). These results are in agreement with those previously published on the rat long (l-rPRLR) and short (s-rPRLR) forms of prolactin receptor (Lebrun et al. 1995a) and, in two ruminant species, on the red deer (rdPRLR) (Jabbour et al. 1996) and bovine (1-bPRLR) (Schuler et al. 1997) long forms of prolactin receptor.

FIGURE 1. Functional characterization of 1-oPRLR and s-oPRLR coding sequences by CAT assay in transiently transfected CHO cells. (A) Schematic representation of 1-oPRLR (557 amino acids), s-oPRLR (272 amino acids) and rbPRLR (592 amino acids). Amino acid 1 is that of the mature protein, after signal peptide removal. The transmembrane domain is represented as a vertically hatched box. Tyrosine residues of the cytoplasmic domains are indicated, and two-headed arrows connect interspecies conserved residues. (B) Prolactin-induced transcription of the ovine $\beta$-lactoglobulin promoter. $\mathrm{CHO}$ cells were transiently co-transfected with PCH110 (encoding the $\beta$-galactosidase), $\mathrm{pBJ} 23$ (the $\beta$-lactoglobulin-CAT construct) and, as indicated, 1-oPRLR-pLKneo, s-oPRLR-pLKneo, or rbPRLR-pLKneo. Prolactin-induced transcription of the CAT gene from the $\beta$-lactoglobulin promoter was conducted as described in Materials and Methods. The results are expressed as the mean of two independent experiments performed in duplicate, \pm half the difference between them. 
Studying prolactin receptor and Jak2 tyrosine phosphorylation requires high levels of expression of the receptor, which cannot be achieved by transient transfection in CHO cells. Therefore, stable CHO clones expressing 1-oPRLR or s-oPRLR were selected. Figure 2A shows the binding capacity of some of these clones. Most of the following experiments were performed with 1-oPRLR-expressing clone L11 and s-oPRLRexpressing clone S9, because they exhibited the highest binding capacities.

Expression and functionality of the two prolactin receptors were evaluated in those two cellular clones. First, Northern blot analysis of total RNA from L11 and S9 revealed easily detectable levels of expression of both transcripts whose sizes were estimated to be 2.6 and $1.8 \mathrm{~kb}$ respectively, in agreement with the size of the inserts $(1.75$ and $0.9 \mathrm{~kb})$ (Fig. 2B). The stronger signal in the L11 lane was more likely to be due to the use of a probe hybridizing $100 \%$ with 1-oPRLR transcript and only partially with s-oPRLR transcript, rather than to a lower expression of the short receptor, since S9 had greater prolactin-binding capacity than L11 (Fig. 2A). Second, L11 and S9 were tested in CAT assay for their ability to stimulate transcription of the $\beta$-lactoglobulin gene in a prolactin-dependent manner. Figure 2C shows $3 \cdot 4$-fold induction of the basic transcription in L11 cells and no induction in S9 cells.

\section{Prolactin-dependent activation of Jak 2 by 1- and s-oPRLR}

Transcription activation of a given gene by a cell membrane receptor is the ultimate step in a cascade of events, some of which have been described to be common to most members of the cytokine receptor superfamily. The first two steps are the concomitant tyrosine phosphorylation of the receptor and of Janus kinases (Jak1, Jak2, Jak3 or tyrosine kinase 2) (Schindler \& Darnell 1995).

We therefore investigated which proteins were tyrosine phosphorylated, in response to prolactin, among those associated with the long or short receptors. With that aim, lysates of L11 and S9 cells, that had been stimulated or not by prolactin, were immunoprecipitated by anti-receptor antibody and blotted with anti-phosphotyrosine antibody. Figure $3 \mathrm{~A}$ shows that prolactin induced 1-oPRLR, but not s-oPRLR, tyrosine phosphorylation. Moreover, a $130 \mathrm{kDa}$ protein was co-immunoprecipitated with 1-oPRLR and s-oPRLR, and was tyrosine phosphorylated in either case in a prolactindependent manner.
Tyrosine phosphorylation of 1-oPRLR was confirmed by a kinetic experiment. Extracts of L11 cells, that had been stimulated for different lengths of time by the same concentration of prolactin, were immunoprecipitated by anti-receptor antibody 46, and blotted with anti-phosphotyrosine antibody. Figure $3 \mathrm{~B}$ shows that 1-oPRLR tyrosine phosphorylation increased up to 5 or $10 \mathrm{~min}$, and then decreased at 30-min incubation.

Jak2, a $130 \mathrm{kDa}$ tyrosine kinase, has been shown to be constitutively associated with the prolactin receptor and to be tyrosine phosphorylated in response to prolactin (Dusanter-Fourt et al. 1994). Therefore, it was tempting to speculate that the $130 \mathrm{kDa}$ protein detected in Fig. 3A was Jak2. This was addressed by immunoprecipitating lysates of L11 and S9 cells, which had been stimulated or not by prolactin, with anti-Jak2 antibody, and then blotting with anti-phosphotyrosine antibody. The results shown in Fig. 3C confirmed this hypothesis, and that Jak2 was tyrosine phosphorylated to the same extent by s- and 1-oPRLR under prolactin stimulation. Thus, prolactin-induced Jak2 activation did not allow discrimination between 1-oPRLR, which transduced the prolactin signal to the ovine $\beta$-lactoglobulin gene promoter and s-oPRLR, which did not.

\section{Prolactin-dependent activation of STAT5 by 1- and s-PRLR}

After Jak2 and receptor tyrosine phosphorylation, the next step of signal transduction common to many members of the cytokine receptor superfamily is the recruitment and activation of STAT5. Once STAT5 has been tyrosine phosphorylated, it dimerizes and translocates to the nucleus where it binds to target promoters to initiate transcription (Gouilleux et al. 1994).

Since Jak2 activation by s-oPRLR was identical to that produced by l-oPRLR we next compared the capacity of the two receptors to stimulate the DNA-binding activity of endogenous STAT5 to STAT5-specific double-stranded oligonucleotide, in EMSA. Figure 4A shows that both 1-oPRLR (lanes 1 and 2) and s-oPRLR (lanes 5 and 6) elicited such an effect in a prolactin-dependent manner. Moreover, comparable supershift patterns of the DNA/protein complexes were obtained in both instances, with anti-STAT5a and anti-STAT5b antibodies (compare lanes 3 and 4 with lanes 7 and 8). Interestingly, anti-STAT5b antibodies did not supershift the whole complex, the non-supershifted complex was therefore essentially made of STAT5a homodimers (lanes 3 and 7). The same reasoning applied to anti-STAT5a antibody supershifts, with 
A

\begin{tabular}{c|c|c|c|c|c|c|}
\hline CHO clone & L3 & L11 & L18 & S2 & S5 & S9 \\
\hline $\mathrm{cpm}$ & 1362 & 7397 & 7002 & 14687 & 7950 & 16477 \\
\hline
\end{tabular}

B

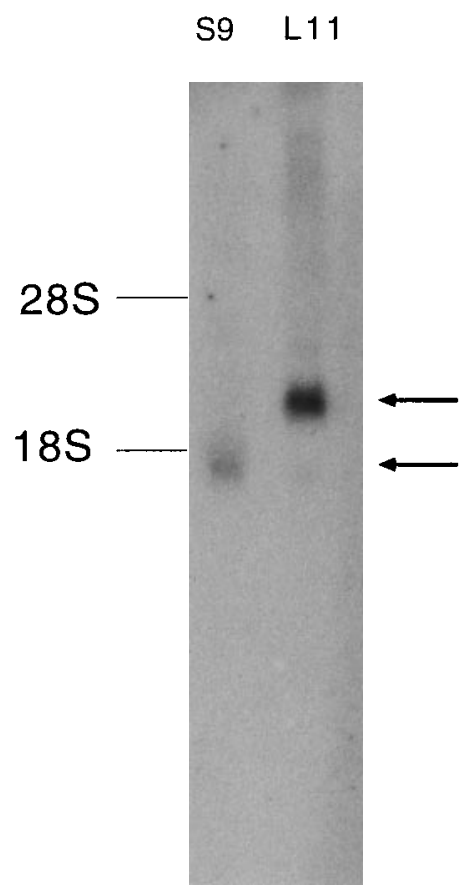

C

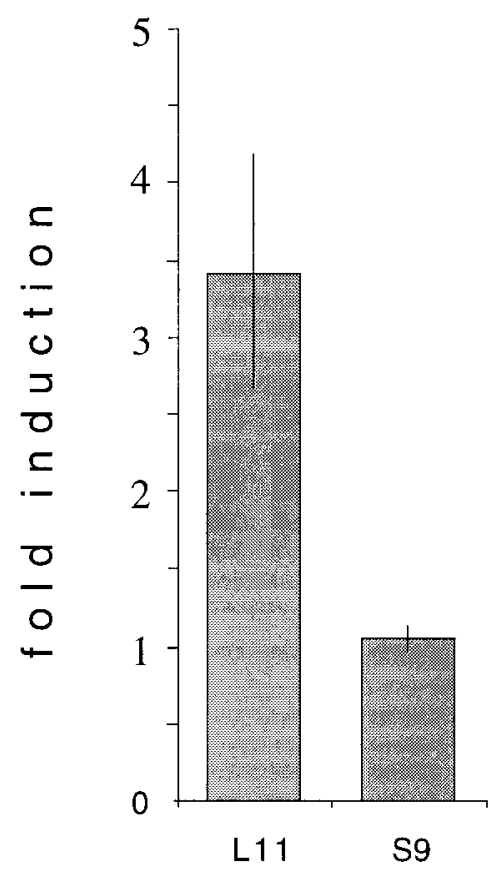

FIGURE 2. Characterization of CHO clones stably expressing 1- and s-oPRLR. (A) Binding capacity of several CHO clones. L3, L11 and L18 are 1-oPRLR-expressing clones; S2, S5 and S9 are s-oPRLR-expressing clones. The binding capacity is expressed in c.p.m., as defined in Materials and Methods. (B) Northern blot analysis of S9 and L11 RNA. The same amount (10 $\mu \mathrm{g})$ of total RNA of S9 and L11 cells was run in 1\% agarose gel, transferred to nylon membrane, and hybridized to ${ }^{32}$ P-labeled 1-oPRLR cDNA. 28S and $18 \mathrm{~S}$ indicate the migration of rRNA. The position of s-oPRLR and 1-oPRLR mRNAs expressed from pLKneo is denoted by two arrows on the right of the blot. (C) Prolactin-induced transcription of $\beta$-lactoglobulin-CAT construct in S9 and L11 CHO clones. S9 and L11 cells were transiently co-transfected with PCH110 (encoding the $\beta$-galactosidase) and pBJ23 (the $\beta$-lactoglobulin-CAT construct), and transcription of the CAT gene from the lactoglobulin promoter was followed as described in Materials and Methods. The results are expressed as the mean \pm S.E.M. of four independent experiments performed in duplicate, and statistical analysis of the data in Mann-Whitney tests indicate that L11 and S9 responses are significantly different $(P<0 \cdot 05)$. 
A

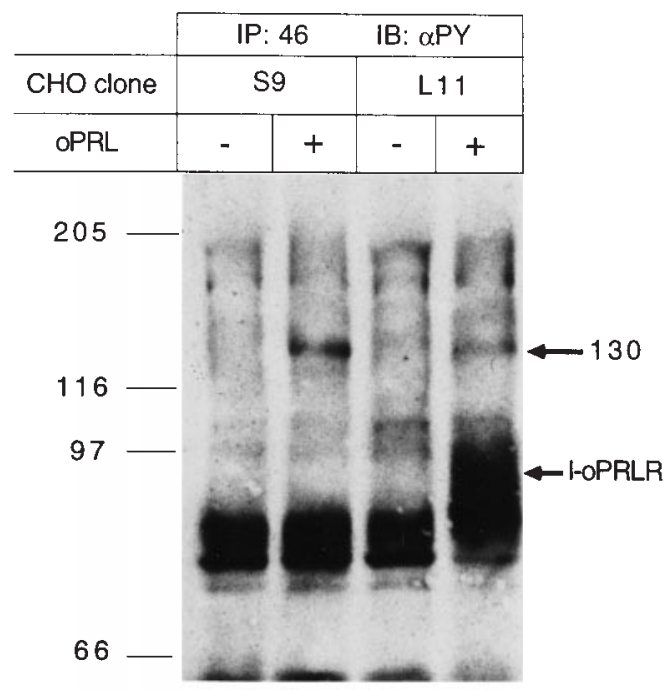

B

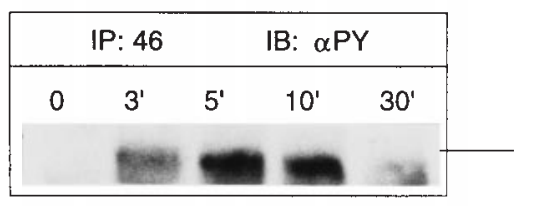

C

\begin{tabular}{|c|c|c|c|c}
\hline \multicolumn{3}{|c|}{ IP: $\alpha$ Jak2 } & \\
\hline \multicolumn{2}{|c|}{ L11 } & \multicolumn{2}{|c|}{ S9 } & CHO clone \\
\hline- & + & - & + & oPRL \\
\hline \hline & & & $\vdots$ & blot $\alpha$ PY \\
\hline & & & & blot $\alpha$ Jak2 \\
\hline
\end{tabular}

FIGURE 3. Prolactin-induced tyrosine phosphorylation of 1-oPRLR and of Jak2. (A) Extracts of S9 and L11 cells, that had been stimulated or not by prolactin for 5 min, were immunoprecipitated by anti-prolactin receptor antibody 46 (IP: 46), resolved by SDS-PAGE and blotted on nitrocellulose. The blot was revealed with anti-phosphotyrosine antibody (IB: $\alpha \mathrm{PY})$. The position of the molecular mass markers is indicated on the left, and that of 1-oPRLR and of the $130 \mathrm{kDa}$ associated protein on the right of the blot. (B) Kinetic of prolactin-induced tyrosine phosphorylation of 1-oPRLR. L11 cells were stimulated by prolactin for different lengths of time and then processed as in (A). The duration of prolactin stimulation is indicated at the top of the blot, and migration of the $97 \mathrm{kDa}$ molecular mass marker on the right. (C) Extracts of S9 and L11 cells, that had been stimulated or not by prolactin for $5 \mathrm{~min}$, were immunoprecipitated by anti-Jak2 antibody (IP: $\alpha \mathrm{J}$ ak2), resolved by SDS-PAGE and blotted on nitrocellulose. The blot was revealed with anti-phosphotyrosine antibody, and then with anti-Jak2 antibody, as indicated. a STAT5b homodimer-enriched non-supershifted complex (lanes 4 and 8). The mainly homodimeric nature of STAT5 dimers in the non-supershifted complexes was strengthened by their slight mobility difference (compare lane 3 with lane 4 , or lane 7 with lane 8), in agreement with STAT5a being seven amino acids larger than STAT5b (Mui et al. 1995). This difference was undetectable in the absence of antibody. Since prolactin-induced STAT $5 \mathrm{a} / \mathrm{b}$ heterodimers have been described in NB2 cells (Kirken et al. 1997) and in mouse mammary gland (Liu et al. 1996) by Western blotting, the band in lanes 2 and 6 could, in fact, be a mixture of STAT5a homodimers, STAT5b homodimers, and STAT5a/b heterodimers. However, we did not investigate this point, because we were unable to set up an experiment which could demonstrate that heterodimers detected by Western blotting have DNA-binding activity. Thus, 1-oPRLR and s-oPRLR appeared to have the same capacity to promote STAT5 DNA binding. Consequently, this step did not provide an explanation for the different transactivation abilities of 1-oPRLR and s-oPRLR with respect to transcription of the ovine $\beta$-lactoglobulin gene.

In order to check that these results were not unique to L11 and S9, other stable clones were screened by EMSA. Figure 4B shows that nuclear extracts of isolated $\mathrm{CHO}$ clones expressing 1-oPRLR (L3 and L11) or s-oPRLR (S2, S5 and S9) all produced the same prolactin-induced DNA/protein complex. This complex was specific because it was not any more visible when the reaction mixture was preincubated with an excess of unlabeled DNA, and also because it was supershifted by anti-MGF antibody (which does not discriminate between STAT5a and b). Only quantitative differences (different band intensities) from one clone to another were noticeable which, interestingly, perfectly matched the prolactinbinding capacities of the clones (Fig. 2A). Incidentally, this indicated that the amount of cell surface receptors, irrespective of whether they were short or long, was the limiting step of STAT5 DNAbinding activation. Thus, STAT5 activation by L11 and S9 was not peculiar to L11 and S9, but was a feature of 1 - and s-oPRLR.

\section{STAT5 DNA-binding activation parallels transcription of a strictly STAT5-dependent promoter}

The fact that s-oPRLR could activate STAT5 DNA binding without increasing $\beta$-lactoglobulin gene transcription clearly established that prolactindependent transcription of this promoter was not 


\begin{tabular}{|c|c|c|c|c|c|c|c|c|}
\hline \multirow[t]{2}{*}{$\mathbf{A}$} & 2 & 3 & 4 & 5 & 6 & 7 & 8 & \multirow[b]{2}{*}{ CHO clone } \\
\hline & \multicolumn{3}{|c|}{ L11 } & \multicolumn{4}{|c|}{ S9 } & \\
\hline- & + & + & + & - & + & + & + & OPRL \\
\hline - & - & - & + & - & - & - & + & $\alpha$ STAT5a Ab \\
\hline- & - & + & - & - & - & + & - & $\alpha$ STAT5b Ab \\
\hline
\end{tabular}
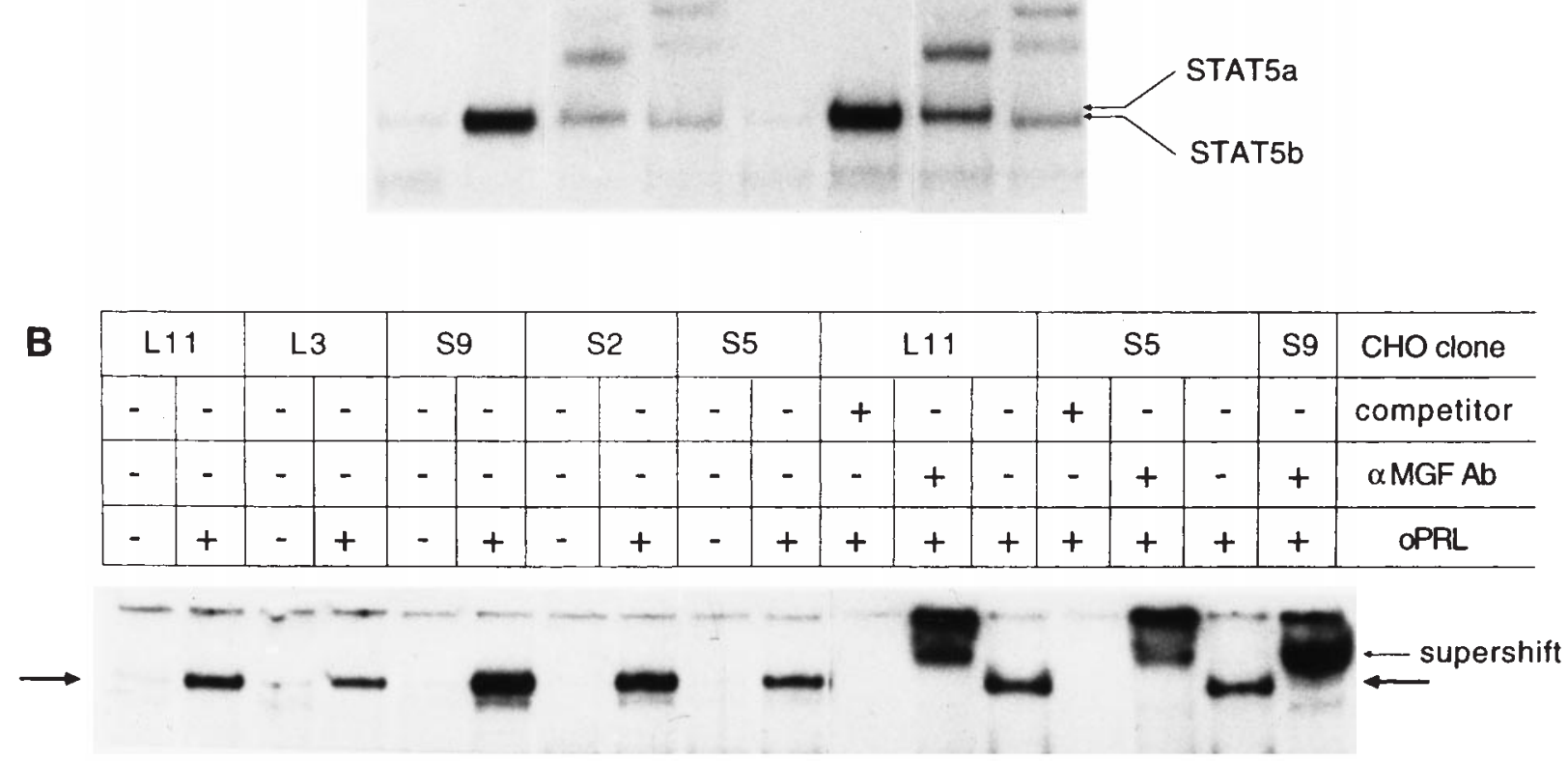

FIGURE 4. Prolactin-dependent activation of STAT5 DNA binding by 1- and s-oPRLR. (A) Nuclear extracts of L11 and S9 cells, that had been stimulated or not by prolactin for $15 \mathrm{~min}$, were incubated with ${ }^{32} \mathrm{P}-\mathrm{labeled}$ double-stranded oligonucleotides as described in Materials and Methods, and then used in EMSA. When indicated, $1 \mu \mathrm{l}$ anti-STAT5a or anti-STAT5b antibody was preincubated with the extracts. In those cases, the relative position of non-shifted STAT5a- and STAT5b-enriched homodimers is indicated on the right of the gel. (B) Nuclear extracts of several 1- and s-oPRLR CHO clones, which had been stimulated or not by prolactin for 15 min, were processed as in (A). When indicated, $1 \mu \mathrm{l}$ anti-MGF antibodies or $1 \mu \mathrm{g}$ unlabeled DNA were preincubated with the extracts. The DNA/protein and supershifted complexes are indicated by an arrow on both sides or by a thin arrow on the right of the blot respectively.

only STAT5 dependent. We therefore speculated that, conversely, if a promoter was only STAT5 dependent, then it should be transactivated by both s-oPRLR and 1-oPRLR, since STAT5 DNAbinding activation was equally mediated by $1-$ and s-oPRLR. Such promoter constructs have been described already (Gao et al. 1996, Sotiropoulos et al. 1996, Stoecklin et al. 1997). One of them is made of six repeats of the rat $\beta$-casein STAT5responsive sequence, located upstream of a thymidine kinase minimal promoter linked to a luciferase reporter gene (LHRE-tk-luc) (Sotiropoulos et al. 1996).
To test the above hypothesis, L11, S9 and F3 (a CHO clone stably expressing s-rPRLR (Boutin et al. 1988)) cells were transfected with LHRE-tkluc construct, and prolactin-dependent increase of luciferase activity was measured. Figure $5 \mathrm{~A}$ shows that LHRE-tk-luc transcription was activated by prolactin to the same extent (three times the level of unstimulated cells) by both 1- and s-oPRLR. By contrast, transcription was not activated by prolactin when LHRE-tk-luc plasmid was transfected into F3, which promoted a barely detectable STAT5 DNA-binding activity under prolactin stimulation (Fig. 5B). Note that, in contrast with 
A

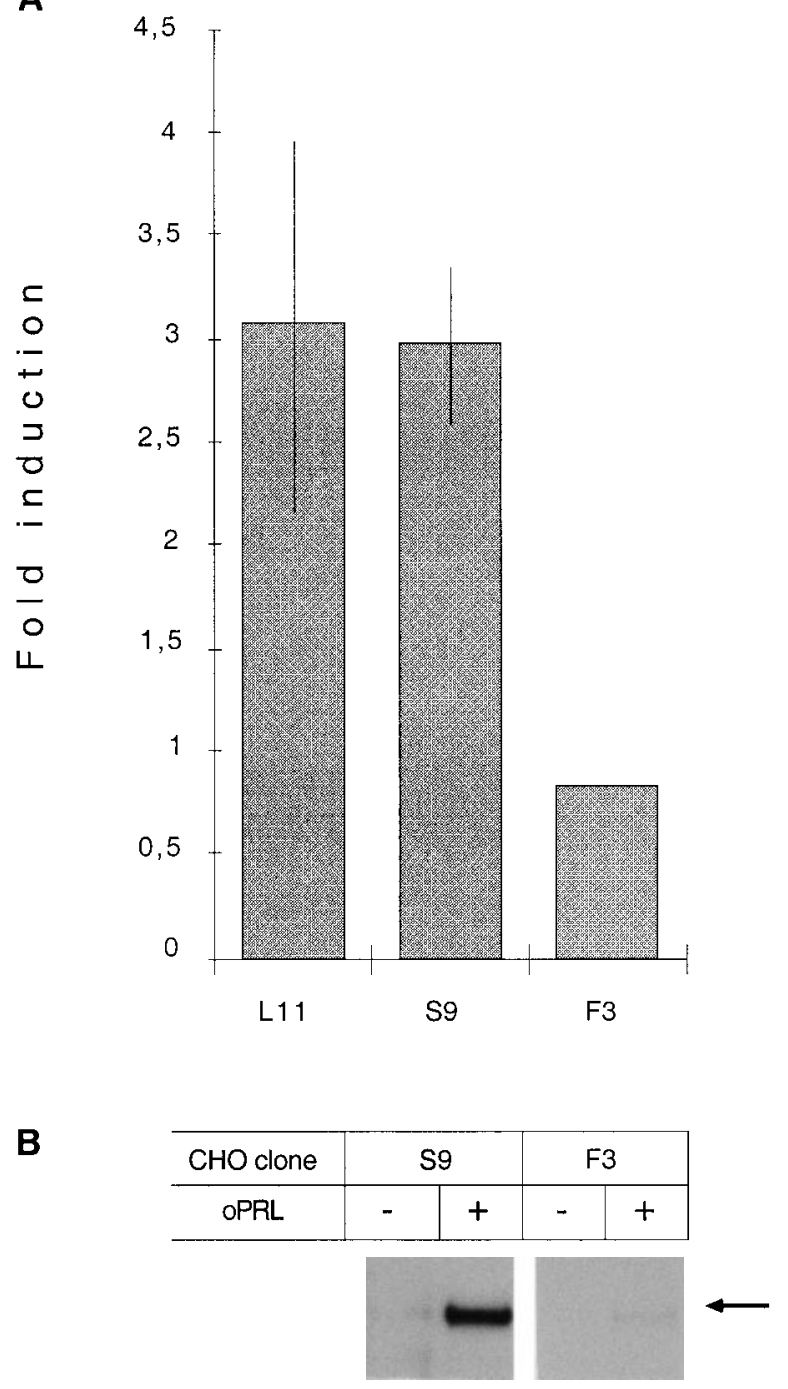

FIGURE 5. Prolactin-dependent stimulation of LHRE-tk-luc transcription reflects STAT5 DNA-binding activation. (A) L11, S9 and F3 clones were transfected with PCH110 (encoding the $\beta$-galactosidase) and LHRE-tk-luc (a construct containing six STAT5 DNA-binding sequences, upstream of thymidine kinase minimal promoter and luciferase coding sequence), and prolactin-induced increase of luciferase gene transcription was followed as described in Materials and Methods. The results are expressed as in Fig. 1B, and are representative of one (F3) or two (L11 and S9) independent duplicate experiments. (B) Nuclear extracts of S9 and F3 cells, that had been stimulated or not by prolactin for $15 \mathrm{~min}$, were processed as in Fig 4.

the fitting we observed between STAT5 DNAbinding activation and the amount of cell surface 1and s-oPRLR (see above), the different STAT5
DNA-binding activation capacities of S9 and F3 were not due to different levels, nor to different affinities for oPRL of the respective receptors, as confirmed by Scatchard analysis $\left(K_{\mathrm{d}}: 0 \cdot 2 \mathrm{nM}\right.$ and $0 \cdot 1 \mathrm{nM}, \quad 53$ and $43 \mathrm{fmol}$ binding sites $/ \mathrm{mg}$ membrane proteins, for $\mathrm{S} 9$ and $\mathrm{F} 3$ respectively (not illustrated)). Thus, STAT5 DNA-binding activation correlated with transcription of a promoter that was only STAT5 dependent.

\section{DISCUSSION}

The availability of full-length coding sequences for 1- and s-oPRLR provided us with an opportunity to functionally test signal transduction partners (ligand, receptors, target promoter) of the same species (sheep), making this cellular system more physiologically relevant than that we used before (Lesueur et al. 1990). In addition, the remaining components of the signaling pathway were endogenous, avoiding ligand-independent activations of Jak2 (Lebrun et al. 1995a, Gao et al. 1996) or of STAT5 (Moriggl et al. 1996) due to overexpression.

In a previous paper, 1-oPRLR cytoplasmic domain was shown to end 38 amino acids before that of 1-rPRLR and rbPRLR. As a consequence, the last tyrosine residue present in the latter two was missing (Y580, Y581) (Bignon et al. 1997). We show here for the first time that a wild-type long form of prolactin receptor, devoid of the last tyrosine residue found in 1-rPRLR (Y580) and rbPRLR (Y581), is tyrosine phosphorylated, in a prolactinand time-dependent manner comparable with that of the two longer receptors (Lebrun et al. 1995b, Waters et al. 1995). By contrast, and in agreement with data reported on s-rPRLR (Lebrun et al. 1995b), s-oPRLR is not tyrosine phosphorylated under the same conditions. The cytoplasmic domain of l-oPRLR contains nine tyrosine residues, and that of rbPRLR only six, five of which are conserved in the ovine sequence (Y237, Y383, Y407, Y488 and Y519, see Fig. 1A). In another paper, we showed that T451, a truncated rbPRLR lacking the last three tyrosines, was not any more tyrosine phosphorylated following prolactin stimulation (Goupille et al. 1997). Thus Y488 and Y519, which correspond in 1-oPRLR to the first two of these three residues, are good candidates to account for 1-oPRLR tyrosine phosphorylation. We anticipate that 1-bPRLR (Scott et al. 1992) and rdPRLR (Jabbour et al. 1996), two ruminant 1-PRLR exhibiting the same lack of Y580/Y581 as 1-oPRLR, would also be tyrosine phosphorylated under the same conditions. In addition, 1-oPRLR transduces the prolactin signal to a milk protein gene promoter, 
as do 1-bPRLR (Schuler et al. 1997), rdPRLR (Jabbour et al. 1996) and T451 (Edery et al. 1994). Therefore, Y580 phosphorylation appears to be an absolute requirement in the rat (Lebrun et al. 1995b), but not in ruminants or the rabbit, for prolactin signal transduction.

Our study also reveals that Jak2, a tyrosine kinase constitutively associated with long (Dusanter-Fourt et al. 1994) and NB2 (Campbell et al. 1994) prolactin receptors, is similarly tyrosine phosphorylated by 1- and s-oPRLR, in response to prolactin. Jak2 was found constitutively associated with s-oPRLR (not shown) as it is with l-oPRLR. This is not surprising since the sequence required for Jak2 recruitment (Lebrun et al. 1995a, Goupille et al. 1997) is present in 1- and s-oPRLR. The same result was previously reported for s-rPRLR in 293 cells; however, in that case, the cells had also been transfected with Jak2 construct (Lebrun et al. 1995a).

Jak2 activation is assumed to result in STAT5 tyrosine phosphorylation, a prerequisite for DNA binding of target promoters (Gouilleux et al. 1994). The long (Wakao et al. 1994) and intermediate (NB2) (Pallard et al. 1995), but not the short rPRLR (Gouilleux et al. 1994) have been shown to induce STAT5 DNA-binding activity. Accordingly, the results we obtained with s-rPRLR (F3) correlate a barely detectable STAT5 DNA-binding activation with the lack of LHRE-tk-luc induction (Fig. 5). This finding could explain, at least in part, the previously reported inability of s-rPRLR to transactivate the ovine $\beta$-lactoglobulin promoter/ CAT construct (Lesueur et al. 1991). Conversely, the definite STAT5 DNA-binding activation by 1and s-oPRLR correlates with effective LHRE-tkluc transactivation. Therefore, the inability of s-oPRLR to transactivate the ovine $\beta$-lactoglobulin gene promoter is not due to an inability of this receptor to promote STAT5 binding to the STAT5-responsive elements of this promoter. This also indicates that, when STAT5-responsive element is multimerized and used away from its native promoter, a negative transcriptional control is lost. In other words, our results strongly suggest that EMSA and experiments using LHRE-tk-luc provide exactly the same information. These artificial promoters should therefore be used with caution, particularly as to how far the results obtained apply to natural promoters, under the pretext that the latter contains the same consensus sequence. A similar discrepancy has been reported in other systems. For instance, STAT5-dependent inhibition of interferon regulatory factor I (IRF-1) transcription under prolactin stimulation is lost when three interferon $\gamma$ activation sequence elements of IRF-1 promoter (it normally contains only one) are located upstream of a minimal thymidine kinase promoter (Luo \& Yu-Lee 1997). Another example is the loss of virus-specific induction of interferon $\beta$ (INF $\beta$ ) promoter when six copies of the positive regulatory domain IV element of INF $\beta$ promoter (which also contains only one normally) are clustered in a synthetic reporter (Thanos \& Maniatis 1995).

Finally, the fact that a short prolactin receptor is able to activate STAT5 is in favor of STAT5 recruitment being mediated, at least in part, by Jak2.

Nevertheless, Jak2/STAT5 activation alone is not sufficient to account for enhanced $\beta$-lactoglobulin gene transcription by prolactin, since s-oPRLR is unable to transactivate the ovine $\beta$-lactoglobulin promoter, although it exhibits the same capacity as 1-oPRLR to activate Jak2, STAT5 DNA binding and LHRE-tk-luc transcription. Similarly, binding of growth hormone and erythropoietin to their respective receptor in transfected COS-7 cells does not transactivate a $(-344$ to -1$) \beta$-casein promoter-luciferase construct, whereas it does activate STAT5 DNA binding (Gouilleux et al. 1995).

The above data could be summarized as follows: under prolactin stimulation, transcription of the original ovine $\beta$-lactoglobulin promoter is enhanced by 1-oPRLR only, although immunoblots and EMSA respectively reveal an identical activation of Jak2 and of STAT5 DNA binding by 1- and s-oPRLR. However, s-oPRLR recovers the same transcriptional efficiency as l-oPRLR when STAT5-binding DNA sequences are used in another context. Therefore, sequences of the native promoter other than STAT5-specific sequences account for the different transcription activation efficiency of the ovine $\beta$-lactoglobulin promoter by 1 - and s-oPRLR.

By contrast, the following potential explanations of the observed data have been disqualified. (1) STAT5 heterodimerization with other STATs has not been reported thus far. (2) In some instances, cytokine-induced modulation of STAT serine phosphorylation has been described to enhance STAT-dependent transcription (Wen et al. 1995, Lüttiken et al. 1995, Pircher et al. 1997). However, a possible prolactin-induced modulation of STAT5 serine phosphorylation could not explain the opposite signaling capacity of 1 - and s-oPRLR because this difference was not observed when LHRE-tk-luc was used as reporter (see Fig. 5). (3) The glucocorticoid receptor has been shown to enhance STAT5-dependent transactivation of the ovine $\beta$-casein promoter through a protein/protein interaction (Stoecklin et al. 1997). However, 
identical DNA/protein complexes were detected in EMSA following prolactin stimulation of 1 - or s-oPRLR (Fig. 4), although the experiments were performed in all cases in the presence of dexamethasone. The same reasoning applies to the prolactin-induced LHRE-tk-luc transactivation (Fig. 5).

The next step of this study is therefore the identification of transcription factors and of their target DNA sequences in the ovine $\beta$-lactoglobulin gene promoter, and how the cytoplasmic domain of 1-oPRLR, but not of s-oPRLR, either of growth hormone or erythropoietin receptors (Gouilleux et al. 1995) activates them. In this regard, s-oPRLR/ 1-oPRLR couple is a promising tool to characterize transcription factors utilized by 1-oPRLR and not by s-oPRLR (activators), or transcription factors used by s-oPRLR and not by l-oPRLR (inhibitors).

\section{ACKNOWLEDGEMENTS}

We thank Professor Paul A Kelly for the gift of LHRE-TK-Luc and of the CHO clone stably expressing the short rat prolactin receptor F3. We also thank Dr Eve Devinoy and Dr Geneviève Jolivet for critical reading of the manuscript.

\section{REFERENCES}

Ali S, Pellegrini I \& Kelly P A 1991 A prolactin-dependent immune cell line (NB2) expresses a mutant form of prolactin receptor. Fournal of Biological Chemistry 266 20110-20117.

Ali S, Edery M, Pellegrini I, Lesueur L, Paly J, Djiane J \& Kelly PA 1992 The NB2 form of prolactin receptor is able to activate a milk protein gene promoter. Molecular Endocrinology 6 1242-1248.

Bignon C, Daniel N \& Djiane J $1993 \beta$-galactosidase ( $\beta$-gal) and chloramphenicol acetyl transferase (CAT) assays in 96-well plates. Biotechniques 15 243-244.

Bignon C, Daniel N, Kermabon AY \& Djiane J 1995 Prolactin induces growth inhibition and promotes differentiation of $\mathrm{CHO}$ cells stably transfected with prolactin receptor complementary DNA. FEBS Letters 358 84-88.

Bignon C, Binart N, Ormandy C, Schuler LA, Kelly PA \& Djiane J 1997 Long and short forms of the ovine prolactin receptor: cDNA cloning and genomic analysis reveal that the two forms arise by different alternative splicing mechanisms in ruminants and in rodents. Fournal of Molecular Endocrinology 19 109-120.

Boutin JM, Jolicoeur C, Okamura H, Banville D, Dusanter-Fourt I, Djiane J \& Kelly PA 1988 Cloning and expression of the rat prolactin receptor, a member of the growth hormone/prolactin receptor gene family. Cell $\mathbf{5 3}$ 69-77.

Boutin JM, Edery M, Shirota M, Jolicoeur C, Lesueur L, Ali S, Gould D, Djiane J \& Kelly PA 1989 Identification of a cDNA encoding a long form of prolactin receptor in human hepatoma and breast cancer cells. Molecular Endocrinology 3 $1455-1461$.
Campbell GS, Argetsinger LS, Ihle JN, Kelly PA, Rillema JA \& Carter-Su C 1994 Activation of JAK2 tyrosine kinase by prolactin receptors in $\mathrm{Nb} 2$ cells and mouse mammary gland explants. Proceedings of the National Academy of Sciences of the USA 91 5232-5236.

Daniel N, Waters MJ, Bignon C \& Djiane J 1996 Involvement of a subset of tyrosine kinases and phosphatases in regulation of the $\beta$-lactoglobulin gene promoter by prolactin. Molecular and Cellular Endocrinology 118 25-35.

Davis JA \& Linzer DIH 1989 Expression of multiple forms of the prolactin receptor in mouse liver. Molecular Endocrinology 3 674-680.

Demmer J, Burdon TG, Djiane J, Watson CJ \& Clark AJ 1995 The proximal milk protein binding factor binding site is required for the prolactin responsiveness of the sheep $\beta$-lactoglobulin promoter in Chinese hamster ovary cells. Molecular and Cellular Endocrinology 107 113-121.

Dusanter-Fourt I, Djiane J, Kelly PA, Houdebine LM \& Teyssot B 1984 Differential biological activities between mono- and bivalent fragments of anti-prolactin receptor antibodies. Endocrinology 114 1021-1027.

Dusanter-Fourt I, Muller O, Ziemiecki A, Mayeux P, Drucker B, Djiane J, Wilks A, Harper AG, Fischer S \& Gisselbrecht S 1994 Identification of JAK protein tyrosine kinases as signaling molecules for prolactin. Functional analysis of prolactin receptor and prolactin-erythropoietin receptor chimera expressed in lymphoid cells. EMBO fournal 13 2583-2591.

Edery M, Jolicoeur C, Levi-Meyrueis C, Dusanter-Fourt I, Pétridou B, Boutin JM, Lesueur L, Kelly PA \& Djiane J 1989 Identification and sequence analysis of a second form of prolactin receptor by molecular cloning of complementary DNA from rabbit mammary gland. Proceedings of the National Academy of Sciences of the USA 86 2112-2116.

Edery M, Levi-Meyrueis C, Paly J, Kelly PA \& Djiane J 1994 A limited cytoplasmic region of the prolactin receptor critical for signal transduction. Molecular and Cellular Endocrinology 102 39-44.

Gao J, Hughes JP, Auperin B, Buteau H, Edery M, Zhuang H, Wojchowski DM \& Horseman ND 1996 Interactions among Janus kinases and the prolactin (PRL) receptor in the regulation of a PRL response element. Molecular Endocrinology 10 847-856.

Gouilleux F, Wakao H, Mundt M \& Groner B 1994 Prolactin induces phosphorylation of Tyr 694 of STAT5 (MGF), a prerequisite for DNA binding and induction of transcription. EMBO Fournal 13 4361-4369.

Gouilleux F, Pallard C, Dusanter-Fourt I, Wakao H, Haldosen LA, Norstedt G, Levy D \& Groner B 1995 Prolactin, growth hormone, erythropoietin and granulocyte-macrophage colony stimulating factor induce MGF-STAT5 DNA binding activity. EMBO Fournal 14 2005-2013.

Goupille O, Daniel N, Bignon C, Jolivet G \& Djiane J 1997 Prolactin signal transduction to milk protein genes: carboxyterminal part of the prolactin receptor and its tyrosine phosphorylation are not obligatory for JAK2 and STAT5 activation. Molecular and Cellular Endocrinology 127 155-169.

Hirt RP, Poulain-Godefroy O, Billotte J, Kraehenbuhl JP \& Fasel N 1992 Highly inducible synthesis of heterologous proteins in epithelial cells carrying a glucocorticoidresponsive vector. Gene 111 199-206.

Ihle JN 1996 STATs: signal transducers and activators of transcription. Cell 84 331-334.

Jabbour HN, Clarke LA, Boddy S, Pezet A, Edery M \& Kelly PA 1996 Cloning, sequencing and functional analysis of a truncated cDNA encoding red deer prolactin receptor: an alternative tyrosine residue mediates beta-casein promoter activation. Molecular and Cellular Endocrinology 123 17-26. 
Kirken RA, Malabarba MG, Xu J, Liu X, Farrar WL, Hennighausen L, Larner AC, Grimley PM \& Rui H 1997 Prolactine stimulates serine/tyrosine phosphorylation and formation of heterocomplexes of multiple STAT5 isoforms in NB2 lymphocytes. Fournal of Biological Chemistry 272 14098-14103.

Lebrun JJ, Ali S, Ullrich A \& Kelly PA $1995 a$ Proline-rich sequence mediated JAK2 association to the prolactin receptor is required but not sufficient for signal transduction. Fournal of Biological Chemistry 270 10664-10670.

Lebrun JJ, Ali S, Goffin V, Ullrich A \& Kelly PA 1995 b A single phosphotyrosine residue of the prolactin receptor is responsible for activation of gene transcription. Proceedings of the National Academy of Sciences of the USA 92 4031-4035.

Lesueur L, Edery M, Paly J, Clark J, Kelly PA \& Djiane J 1990 Prolactin stimulates milk protein promoter in $\mathrm{CHO}$ cells co-transfected with prolactin receptor cDNA. Molecular and Cellular Endocrinology 71 7-12.

Lesueur L, Edery M, Ali S, Paly J, Kelly PA \& Djiane J 1991 Comparison of long and short forms of the prolactin receptor on prolactin-induced milk protein gene transcription. Proceedings of the National Academy of Sciences of the USA 88 824-828.

Liu X, Robinson GW, Gouilleux F, Groner B \& Hennighausen L 1995 Cloning and expression of STAT5 and an additional homologue (STAT5b) involved in prolactin signal transduction in mouse mammary tissue. Proceedings of the National Academy of Sciences of the USA 92 8831-8835.

Liu X, Robinson GW \& Hennighausen L 1996 Activation of STAT5a and STAT5b by tyrosine phosphorylation is tightly linked to mammary gland differentiation. Molecular Endocrinology 10 1496-1506.

Liu X, Robinson GW, Wagner KU, Garrett L, Wynshaw-Boris A \& Hennighausen L 1997 STAT5a is mandatory for adult mammary gland development and lactogenesis. Genes and Development 11 179-186.

Luo G \& Yu-Lee L 1997 Transcriptional inhibition by STAT5. Differential activities at growth-related versus differentiation-specific promoters. Fournal of Biological Chemistry 272 26841-26849.

Lütticken C, Coffer P, Yuan J, Schwartz C, Caldenhoven E, Schindler C, Kruijer W, Heinrich P \& Horn F 1995 Interleukin-6-induced serine phosphorylation of transcription factor APRF: evidence for a role in interleukin-6 target gene induction. FEBS Letters 360 137-143.

Moore RC \& Oka T 1993 Cloning and sequencing of the cDNA encoding the murine mammary gland long-form prolactin receptor. Gene 134 263-265.

Moriggl R, Gouilleux-Gruart V, Jähne R, Berchtold S, Gartmann C, Liu X, Hennighausen L, Sotiropoulos A, Groner B \& Gouilleux F 1996 Deletion of the carboxy-terminal transactivation domain of MGF-Stat5 results in sustained DNA binding and a dominant negative phenotype. Molecular and Cellular Biology 16 5691-5700.

Mui AL, Wakao H, O'Farrell AM, Harada N \& Miyajima A 1995 Interleukin-3, granulocyte-macrophage stimulating factor and interleukin-5 transduce signals through two STAT5 homologs. EMBO Fournal 14 1166-1175.

O’Neal KD \& Yu-Lee LY 1994 Differential signal transduction of the short, Nb2, and long prolactin receptors. Fournal of Biological Chemistry $26926076-26082$.

Pallard C, Gouilleux F, Charon M, Groner B, Gisselbrecht S \& Dusanter-Fourt I 1995 Interleukin-3, erythropoietin, and prolactin activate a STAT5-like factor in lymphoid cells. Fournal of Biological Chemistry 270 15942-15945.

Pierre S, Jolivet G, Devinoy E \& Houdebine LM 1994 A combination of distal and proximal regions is required for efficient prolactin regulation of transfected rabbit $\alpha \mathrm{S} 1$-casein gene chloramphenicol acetyl transferase constructs. Molecular Endocrinology 8 1-11.

Pircher TJ, Flores-Morales A, Mui ALF, Saltiel AR, Norstedt G, Gustafsson JA \& Haldosen LA 1997 Mitogen-activated protein kinase inhibition decreases growth stimulated transcription mediated by STAT5. Molecular and Cellular Endocrinology 133 169-176.

Sambrook J, Fritsch EF \& Maniatis T 1989 Molecular Cloning: A Laboratory Manual, edn 2. Cold Spring Harbour, New York: Cold Spring Harbor Laboratory.

Schindler C \& Darnell JE 1995 Transcriptional responses to polypeptide ligands: The JAK-STAT Pathway. Annual Review of Biochemistry 64 621-651.

Schmitt-Ney M, Happ B, Ball RK \& Groner B 1992 Developmental and environmental regulation of a mammary gland-specific nuclear factor essential for transcription of the gene encoding $\beta$-casein. Proceedings of the National Academy of Sciences of the USA 89 3130-3134.

Schuler LA, Nagel RJ, Gao J, Horseman ND \& Kessler MA 1997 Prolactin receptor heterogeneity in bovine fetal and maternal tissues. Endocrinology 138 3187-3194.

Scott P, Kessler MA \& Schuler LA 1992 Molecular cloning of the bovine prolactin receptor and distribution of prolactin and growth hormone receptor transcripts in fetal and utero-placental tissues. Molecular and Cellular Endocrinology 89 47-58.

Shirota M, Banville D, Ali S, Jolicoeur C, Boutin JM, Edery M, Djiane J \& Kelly PA 1990 Expression of two forms of prolactin receptor in rat ovary and liver. Molecular Endocrinology 4 1136-1143.

Sotiropoulos A, Moutoussamy S, Renaudie F, Clauss M, Kayser C, Gouilleux F, Kelly PA \& Finidori J 1996 Differential activation of STAT3 and STAT5 by distinct regions of the growth hormone receptor. Molecular Endocrinology 10 998-1009.

Stoecklin E, Wissler M, Moriggl R \& Groner B 1997 Specific DNA binding of STAT5, but not of glucocorticoid receptor is required for their functional cooperation in the regulation of gene transcription. Molecular and Cellular Biology 17 6708-6716.

Thanos D \& Maniatis T 1995 Virus induction of human IFN $\beta$ gene expression requires the assembly of an enhanceosome. Cell 83 1091-1100.

Tourkine N, Schindler C, Larose M \& Houdebine LM 1995 Activation of Stat factors by prolactin, interferon- $\gamma$, growth hormones, and a tyrosine phosphatase inhibitor in rabbit primary epithelial cells. Fournal of Biological Chemistry 270 20952-20961.

Vilotte JL \& Soulier S 1992 Isolation and characterization of the mouse $\alpha$-lactalbumin-encoding gene: interspecies comparison, tissue- and stage-specific expression. Gene 119 287-292.

Wakao H, Gouilleux F \& Groner B 1994 Mammary gland factor (MGF) is a novel member of the cytokine regulated transcription factor gene family and confers the prolactin response. EMBO Fournal 13 2182-2191.

Waters M, Daniel N, Bignon C \& Djiane J 1995 The rabbit mammary gland prolactin receptor is tyrosine phosphorylated in response to prolactin in vivo and in vitro. Fournal of Biological Chemistry 270 5136-5143.

Wen Z, Zhong Zhong \& Darnel JE 1995 Maximal activation of transcription by STAT1 and STAT3 requires both tyrosine and serine phosphorylation. Cell 82 241-250.

REVISED MANUSCRIPT RECEIVED 6 April 1999 